\title{
ASSESSMENT OF THE ENERGY DEMANDS FOR HEATING IN AN HISTORIC BUILDING. CASE STUDY: RENEWAL OF A FUNCTIONALIST BUILDING OF THE INFECTIOUS DISEASES PAVILION IN TOPOLČANY, SLOVAKIA
}

Andrea VARGOVÁ ${ }^{*}$, Rastislav INGELI'

\section{Abstract}

The case study seeks an optimal solution for preserving the cultural values of a functionalist building so that it fulfils the legislative essence of the protection of a historic building and, at the same time, contributes to the improvement of its thermophysical properties. The paper focuses on the degree of the application of energy performance requirements for the adaptive reuse of a historic building. The efforts to preserve cultural values (architectural, aesthetic, the value of the authenticity of an area and its building constructions, etc.) in legally protected buildings often do not permit the application of building construction processes such as those used in ordinary older buildings. The research responds to a situation where a building with historic values, built in a functionalist style (the 1940s), permits variants of the surface treatment of the facade so as to not disturb the essential stylistic values of that facade and, at the same time, reduce its energy demands to the required value.

Heat demands for heating have a significant effect on the energy needs for heating and thus on the overallenergyneed of a building. The heat demands depend on the efficiency and quality of the thermal protection in buildings. In the case of cultural monuments, the calculation of the thermophysical properties of building structures forms the basis for determining the heating and cooling demands. Building structures and their elements that form the building envelope must meet current and demanding thermophysical requirements in accordance with the applicable standards, if technically and economically feasible. When restoring cultural monuments in the Slovak Republic, it is not required to meet requirements for energy efficiency. On the other hand, it is necessary to verify the thermophysical requirements in accordance with the applicable standards in each specific case.

The paper responds to a continuing interdisciplinary discussion on this topic. The analysis is conducted within the scope of the KEGA016STU-4/2017 project.
Address

1 Dept. of Building Construction, Faculty of Civil Engineering Slovak University of Technology in Bratislava, Slovakia

* Corresponding author: andrea.vargova@stuba.sk

\section{Key words}

- Interdisciplinarity,

- Adaptation of historic building

- Building energy assessment,

- Hygienic criterion,

- Indoor environmental quality.

\section{INTRODUCTION}

When designing buildings, it is essential to assess the energy performance of buildings (Polomová et al. 2017; Kobetič 2020; Energy efficiency 2002). It is necessary that buildings should have energy consumption as low as possible, because it contri- butes to reducing costs as well as reducing $\mathrm{CO} 2$ production (Energy End-Use Efficiency 2006). One of the most important factors is the correct design of external cladding compositions that define the heat exchange of a building envelope. Energy performance requirements (Energy Performance of Buildings 2010) apply to all buildings except for selected categories. One of these categories is 
cultural monuments (historic buildings). If an owner invests in a cultural monument, they expect that the real energy consumption will not be high. This means that it is not only a relatively high investment for its restoration (as well as its modernization and adaptation), but also for the building operation itself. Therefore, it is necessary to look at cultural monuments in terms of their real energy costs. In order to increase the share of the restoration of cultural monuments, these buildings must include a healthy indoor environment and low operating costs.

The subject of the paper is a building proposed for the Cultural Heritage List. The Infectious Diseases Pavilion is an historical building structure situated in a conservation area. The Infectious Diseases Pavilion is located on a flat terrain in Topol'čany, Slovakia, on the left bank of the Chotina river of the so-called "old hospital in Topol'čany", which belongs to the protected monument zone on "Štummerova Street in the area of the old hospital". The area in question is also part of an urban protection zone. The building at issue can be accessed relatively easily by two secondary roads without disturbing the original buildings. This degree of operational independence within the complex provides for its autonomous operation and functional independence, which is advantageous for the phased renovation of the individual buildings dating from the turn of the 19th and 20th centuries. The original idea of building a new infectious disease pavilion originated in the 1920s, especially after several epidemics of infectious diseases. A number of hospital building renovations since 1934 culminated in the announcement of an architectural competition for a new infectology pavilion in 1937. The winning design was a design by Ing. arch. Josef Nowotný, an architect from Bratislava. Construction started at the end of 1939. The building was put into use in 1943 , with a capacity of 70 beds, including 43 beds for children and 27 for adults. The construction was completed in 1943. The design is in the functionalist style, which is evident both in its exterior and interior.

The character of the building can be classified as functionalist, both in its form and in terms of its operational-dispositional solutions. It has one semi-recessed underground floor and three above-ground floors with patient rooms. It has a saddle roof with hipped slopes. The building demonstrates a suitable volume proportionality; the raised basement permits sufficient ventilation in accordance with its use. The functionalist elements of the façade appropriately reflect its internal function. The architecture also features open corners. The architect's maturity and experience in design, including hospitals as well as practical construction experience, were manifested in the building. The operational concept was designed with respect to the cardinal directions and creates a clear layout; i.e., the patient rooms face the southeast (SE), and the staff work area (ambulance, hygiene, food, etc.) is located on the northwest (NW). The layout of the hospital presents a double-loaded corridor system; however, the building structurally creates a single-loaded corridor system (Figure 6). It is effective in terms of its load-bearing systems. Many construction details in the hospital's interior testify to its original and modern design. It is a comprehensively preserved architectural work, so it is important to approach the renovation in accordance with its architectural value, including the modification of the facade surfaces. There are similar buildings from the first half of the 20th century in Slovakia. The procedure for preparing the renovation is based on knowledge of the architectural quality and variants of the functional adaptation (Polomová et al. 2017).

Part of the interdisciplinary approach within the KEGA 016STU-4/2017 project is the architectural and layout concepts for the restoration and adaptation of the original Infectious Diseases Pavilion into a social care home. The building has not been used for about 5 years but still remains in relatively good technical condition. The new concept for the renovation uses the original architectural and design solutions as well as the layout of the hospital building itself. The architectural studies have preserved the articulation (division) of the structure and the colour of the facade in the new design. The original double-wing wooden windows are preserved on the facades on the upper floors. In the basement, metal grilles have been installed on the windows. The window structures are double or single-leaf casement windows with a fixed cross-member mounted in the middle or at two thirds of the window's height. Above the crossbar, there is a bottom hung window controlled by an accessible mechanism, which allows for a gentler but continuous ventilation of the original hospital rooms, which still have their original simple glazed windows. The window frames are fitted approximately $150 \mathrm{~mm}$ from the outer surface of the facade, which results in the formation of shadows. The shadows create a basic modeling element of the views, which the concept for the restoration and adaptation takes into account when solving the facade structures. The proposed adaptation of the existing building has also considered the creation of a shape copy of the window structures, while maintaining the division of the windows and the refurbishment of the original windows according to the results of the technical inspection. The architectural values of the functionalist style also include a tall metal-encased window next to both staircases. The special renovation approach will require elements of considerable size, namely, a reinforced concrete awning above the entrance to the building, a ledge, a terrace and a loggia.

In order to achieve the optimal thermophysical parameters, it is necessary to consider additional thermal insulation and the simultaneous replacement of the glazing system. However, the proposed additional thermal insulation of the building also requires the approval of the Office for Cultural Monuments, as all interventions involving the structure require a statement from the Monument Office. In most cases, it is not possible to insulate the exterior walls from the outside, so as not to damage the relief and structure of the original facade and to preserve the original essence and character of a building. An optional variant for the owner of a building is to apply internal insulation to existing buildings. In this case, however, there is a problem of the formation of other thermal bridges (Tadeu et al. 2011; Act No. 300/2012; Ingeli et al. 2016; Theodosiou et al. 2008), which significantly occur in such types of buildings. Such a solution has both disadvantages and advantages (Williams Portal 2011), i.e., there is a reduction in usable space, but, at the same time, lower operating costs. The paper focuses on an analysis of the perimeter wall insulation in two variants. The first insulation variant is from the outside, and the second insulation is a variant from the inside of the external wall.

The alternatives and the suitability of the thermal insulation layer applied in terms of the protection of monuments are different (Tadeu et al. 2011). The question of whether thermal insulation and the improvement of the thermo-technical properties of an historic building are needed has been addressed by Meier (Meier 2010).

From an architectural and constructional point of view, it is possible to apply an additional thermal insulation system to the functionalist building investigated from the outside of the external wall. The facades of the building represent flat surfaces which, even with the application of thermal insulation, retain the characteristic elements of a functionalist building. 


\section{ANALYSIS OF THE ENERGY EFFICIENCY OF THE SELECTED CULTURAL MONUMENT IN A PROTECTED AREA}

An important factor that affects historic buildings after a certain period of their exploitation is the methods and concepts for their renovation. The direction of current renovations includes research on new materials and the application of simulations, which are considered as a new means to better understand what will happen to an historic building after its renewal. The connection between research on new materials and simulations with in situ measurements is seen as an indispensable tool in examining the structure of historic buildings and designing their renovation more effectively (Matiašovský et al. 2012; Meier 2010). Other key topics in this area are, in particular, research on the indoor environments in historic buildings and damage to historic artefacts due to moisture and heat (Zumoberhaus 2009).

The aim of this section is to prepare and assess various calculation variants of an additional thermal insulation system for the Infectious Diseases Pavilion of the old hospital area in Topol'čany. The building is in its original condition. One specific structural unit is being assessed, namely, the external basement wall made of reinforced concrete, which is partially sunken into the terrain. The assessed corner of the interior is located in the underground part. To compare the results achieved, variants of the construction details were processed: $a$ / with additional internal and $b$ / with additional external thermal insulation of the basement wall. In addition, both variants for the application of the additional thermal insulation are permissible in the case of a functionalist building. The building's condition after implementation of the additional thermal insulation is assessed in terms of the energy criteria in accordance with STN 73 0540-2: 2012 - Z1 / 2012 + Z2 / 2019. In addition to the location of the thermal insulation itself, various thicknesses of the thermal insulation on the external wall of the basement have also been modelled. Insulating the exterior cladding subsequently not only brings advantages but also disadvantages from an architectural point of view (Williams Portal 2011).

\subsection{The assessed building structure}

The building of the Infectious Diseases Pavilion in Topol'čany (Figure 1) is currently unused, as it is in an unsuitable operational

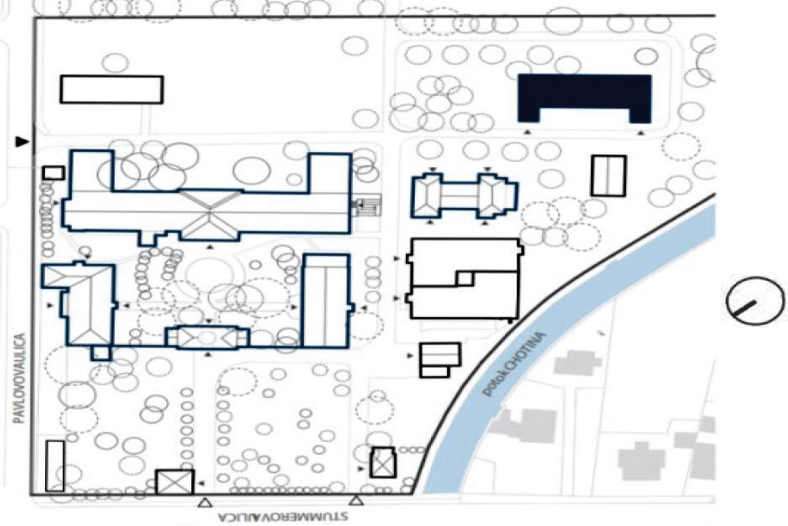

Fig. 1 Situation of the hospital complex showing the building structure examined. The patient rooms are oriented towards the southeast (SE) and the corridors to the northwest (NW)

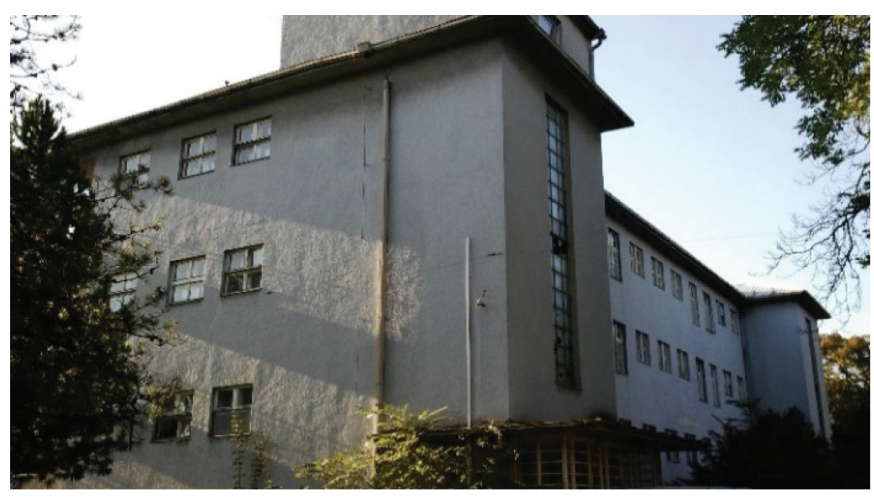

Fig. 2 Northeast elevation

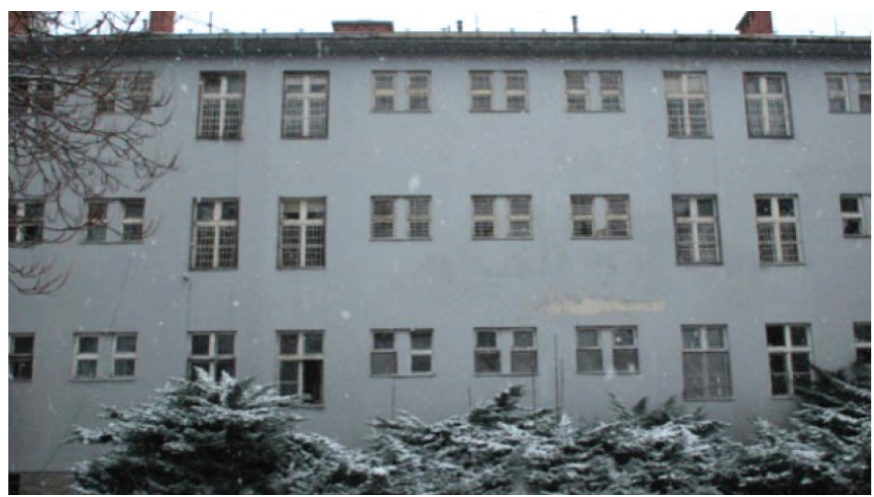

Fig. 3 Northwest elevation

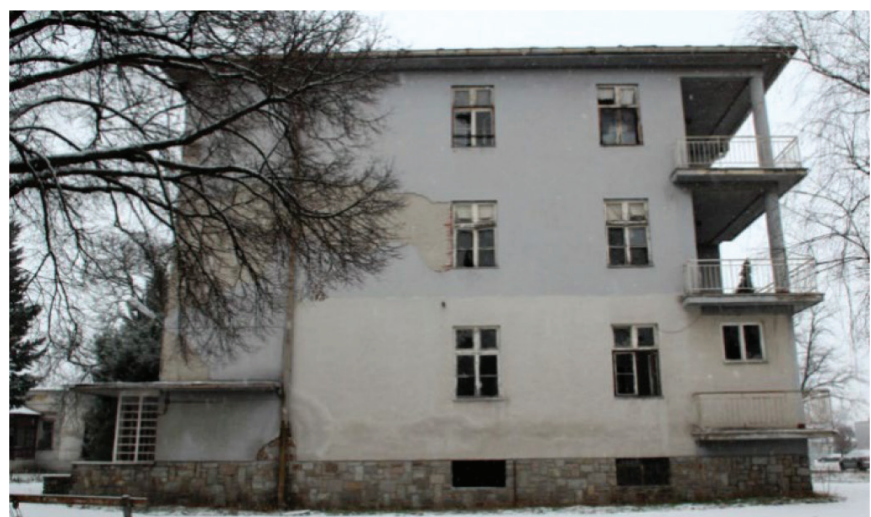

Fig. 4 Southwest elevation with a southerly orientation of the loggias

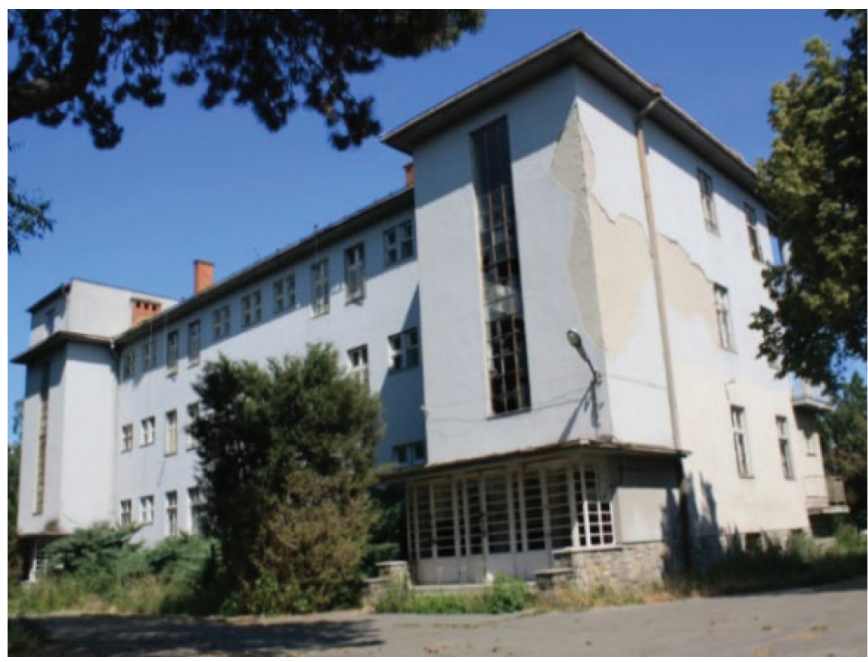

Fig. 5 Northwest elevation 

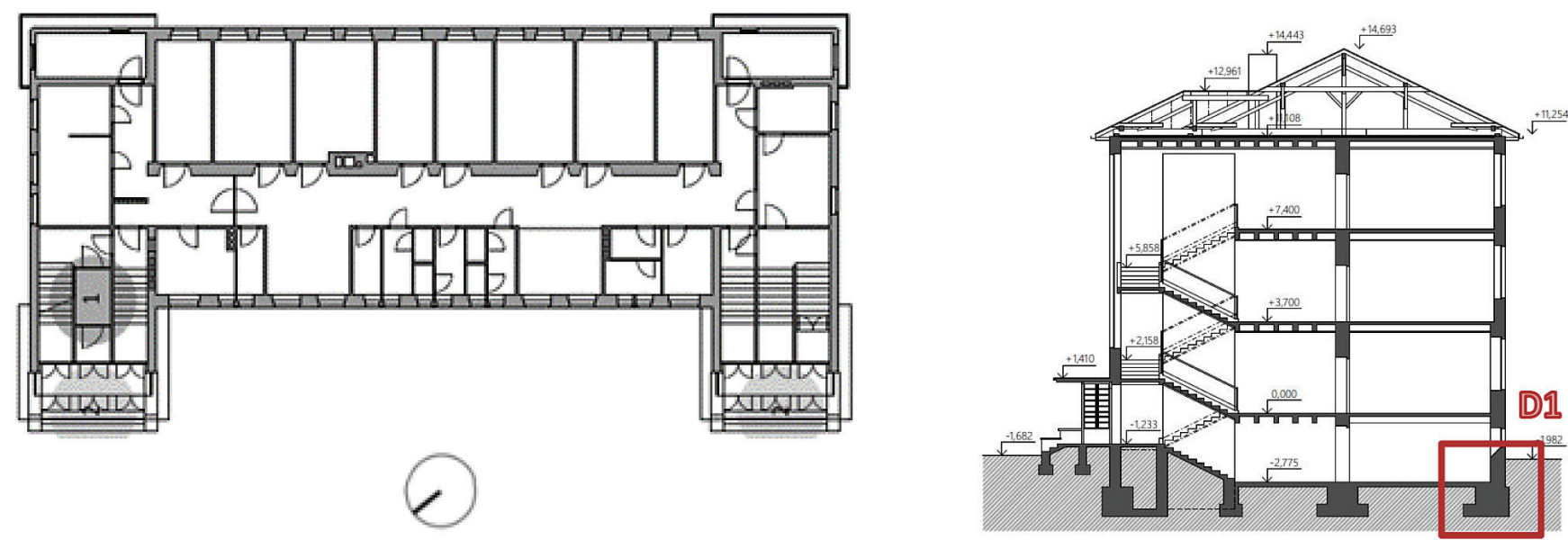

Fig. 6 Ground plan and section elevation of the Infectious Diseases Pavilion building with the assessed detail D1 indicated

condition. Therefore, its extensive renovation is necessary, while it is essential to preserve the original appearance of the building in both its exterior and interior (Figures 2 and 6 ) in terms of the requirements for monument protection.

\subsection{Solution for the construction and building layout}

The pavilion is a free-standing 4-storey building with two risalits (projections) located on the northwest front façade that serve as stairs (Figure 5). An elevator is located in one of the stairwell holes. The layout of the building presents a double-loaded corridor system, and a corridor in the middle connects the two stairs. The patient rooms are oriented towards the southeast (SE). There is a northwest-facing service area opposite the patient rooms. The patient care rooms face the southwest (SW) and the healthcare staff rooms are located on the northeast (NE). The corners of the building oriented towards the southeast and southwest were formed by open loggias on each floor, which were bricked up on the ground floor in the second half of the 20th century.

\subsection{Design and analysis of the additional thermal insulation system}

The building perimeter is very simple: it has a rectangularly shaped plan, and the surface of the facades is flat. These factors allow for the relatively simple implementation of thermal insulation on large areas of the facades (Figure 6). The critical construction detail of the thermal insulation system is resolved on the building envelope, which is made of reinforced concrete, in a corner at the contact between two $450 \mathrm{~mm}$ thick reinforced concrete walls. The critical detail, which represents the original state of the structure, is marked as the original variant with the number 0 (Variant $0)$. The external reinforced concrete wall on both the interior and exterior has the original lime-cement plaster. The first to the third variants of the detail are resolved as an external wall with additional interior wall insulation from Sto-Perlite-Innendämmplatte 045 perlite boards; we considered thermal insulation thicknesses of $60 \mathrm{~mm}, 140 \mathrm{~mm}$, and $200 \mathrm{~mm}$ in the calculations. The fourth to sixth variants of the detail are resolved as an external wall insulated externally with Nobasil SMART wall S C1 mineral wool, while the thermal insulation thicknesses of $60 \mathrm{~mm}, 140 \mathrm{~mm}$, and $200 \mathrm{~mm}$ are considered in the calculations.

\subsection{Boundary conditions input and the thermal properties of the materials used in the calculations}

The following tables show the thermal properties of the materials used in the calculation method and the boundary conditions that were considered in the PSI-Therm calculation program, which was used for the analysis of the individual variants (PsiTherm 2017).

The PSI Therm software provides a thermal bridge analysis of a building construction in which it automatically generates a mesh in order to ensure accurate results in accordance with the ISO 10211 standard. It includes a database of the boundary conditions for an analysis according to BR497 and the passive house conventions, thereby eliminating complicated tables and numerous external calculations. The PSI Therm software generates U-values, Psi values, and Frsi-values, thus producing comprehensive outputs in accordance with the requirements of the international standards.

Tab. 1 Material properties

\begin{tabular}{|l|c|c|}
\hline Material & $\begin{array}{c}\text { Thickness } d \\
\text { in "m" }\end{array}$ & $\begin{array}{c}\text { Thermal con- } \\
\text { ductivity } \lambda \text { in } \\
\text { "W/(m.K)" }\end{array}$ \\
\hline Lime plaster (Baumit Clima UNI) & 0.01 & 0.88 \\
\hline Cement plaster (Baumit Sanova S) & 0.02 & 0.8 \\
\hline Lime - cement plaster (original) & 0.02 & 0.99 \\
\hline Silicate plaster & 0.003 & 0.7 \\
\hline Mineral spatula & 0.005 & 0.8 \\
\hline Cement - based adhesive mortar & 0.005 & 0.8 \\
\hline Perlite insulation & $0.06-0.20$ & 0.045 \\
\hline Mineral wool insulation & $0.06-0.20$ & 0.045 \\
\hline Reinforced concrete & 0.45 & 1.6 \\
\hline Burnt clay bricks & 0.45 & 0.81 \\
\hline Soil & - & 2.3 \\
\hline
\end{tabular}




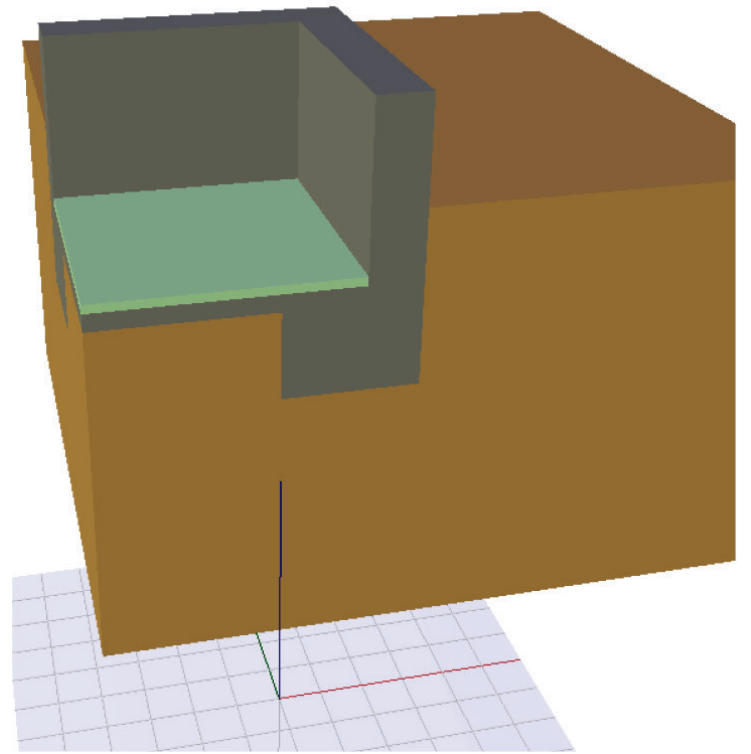

Fig. 7 Modelling the Constructional Detail

The finite element mesh calculations are performed in accordance with EN ISO 10211 (Psi-Therm 2017).

Tab. 2 Boundary conditions

\begin{tabular}{|l|c|l|}
\hline Boundary conditions & $\begin{array}{l}\text { Temperature } \theta \\
\text { in "o } \mathrm{C} \text { " }\end{array}$ & $\begin{array}{l}\text { Heat transfer resistance } R_{\mathrm{s}} \\
\text { in " } \mathrm{m}^{2} . \mathrm{K} / \mathrm{W} "\end{array}$ \\
\hline Exterior - Topol'čany & -11 & 0.04 \\
\hline Interior & 20 & 0.25 \\
\hline
\end{tabular}

\subsection{Assessment of the critical details}

The subject of the assessment of the hygienic criteria is the inner corner (Figure 7). The boundary conditions are shown in Table 2, which is an analysis of the effect of different types of insulation on the internal temperature in the corner selected in the computational model. We have considered that the internal floor of the basement will be insulated with $100 \mathrm{~mm}$ thick thermal insulation. As is the case of historic buildings in general, it is technically feasible. The exact model that was considered for the given calculations and their variants is shown in Figure 8.

Figure 9 shows an illustrative output from the simulation program. This is the output of Variant 0 , i.e., an original detail of the existing state without any additional thermal insulation. As can be seen with the concrete structure itself, the thermal physics requirement is not meet.

Figure 10 shows the output for Variant 6 , where additional thermal insulation is used on the exterior of the basement walls with a thickness of $200 \mathrm{~mm}$. An example for modeling a wall insulated from the inside is presented by Variant 3 in Figure 11. Only the variant of the external wall in the basement based on reinforced concrete was used for the calculations. It is a partially recessed first underground floor as presented in Figure 8.

\subsection{Results of the critical surface temperature analysis}

The resulting surface temperatures for the corner of the 3D critical detail analyzed are shown in the following tables and fig-
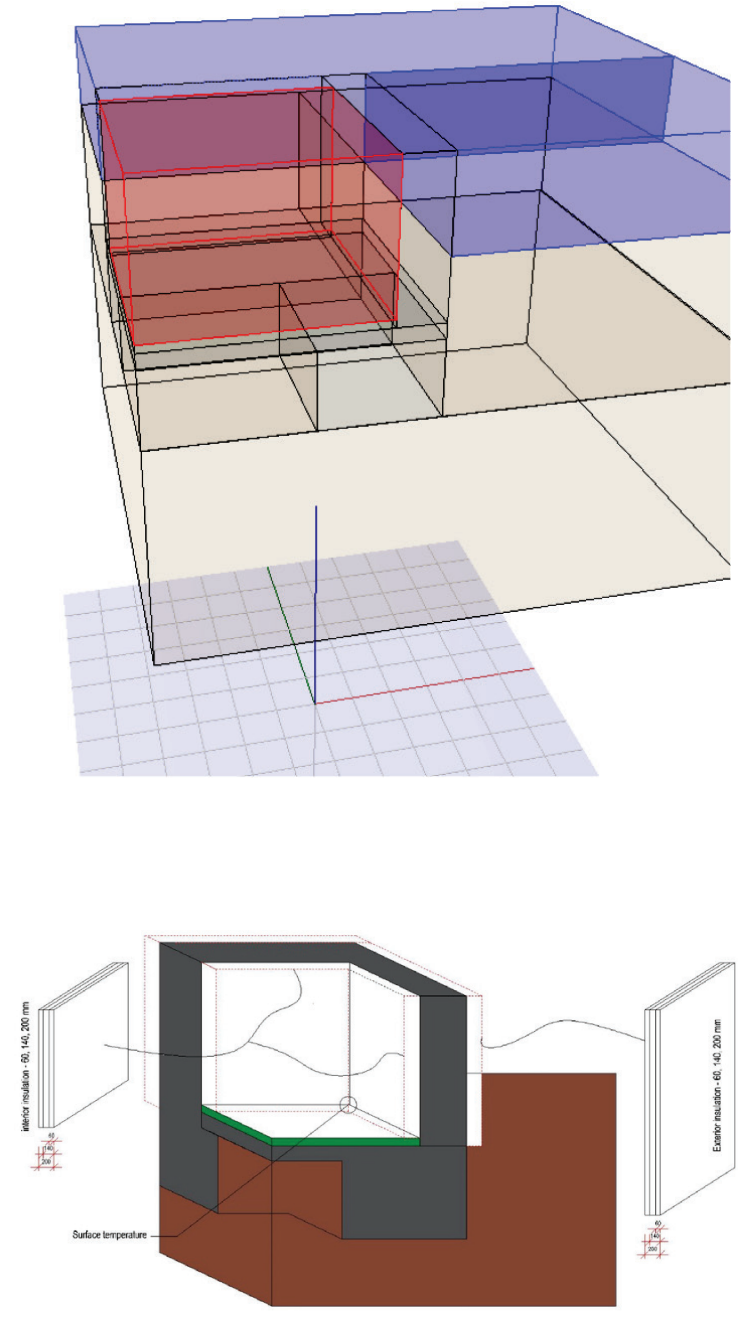

Fig. $83 D$ view of the application of the thermal insulation

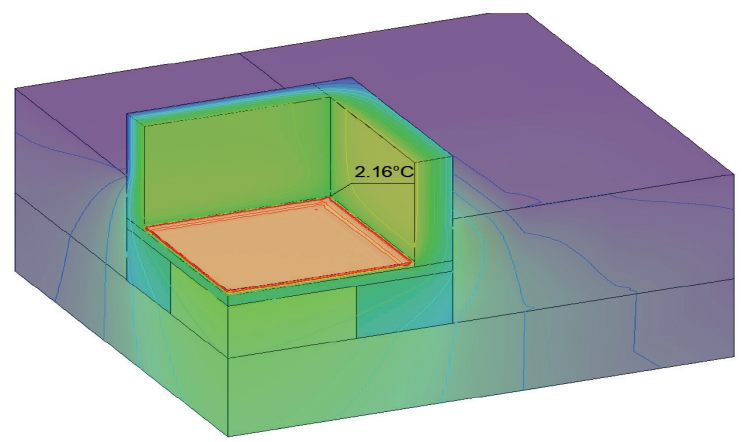

Fig. 9 Temperature profile for Variant 0 without any additional thermal insulation considered

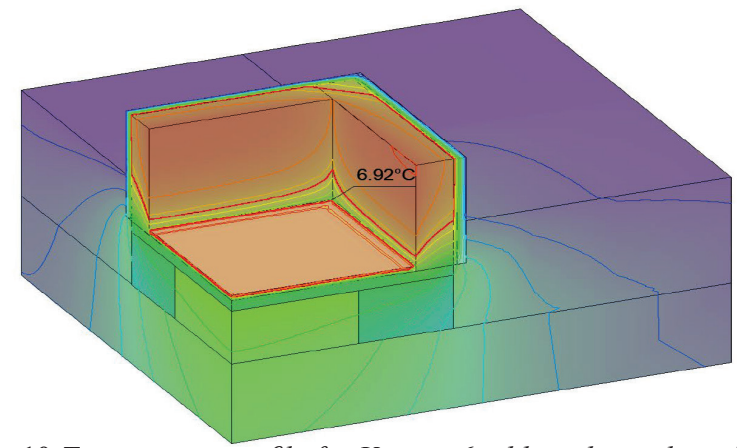

Fig. 10 Temperature profile for Variant 6 adding thermal insulation with a thickness of $200 \mathrm{~mm}$ on the exterior side in the basement 


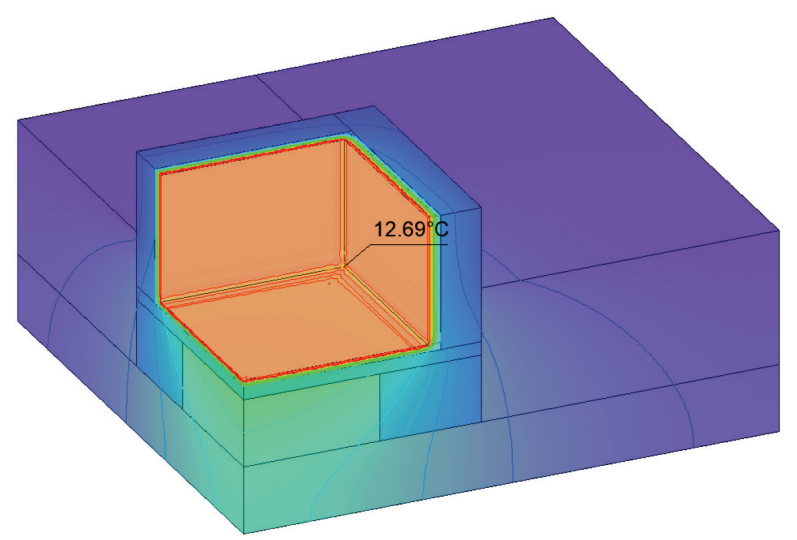

Fig. 11 Temperature profile for Variant 3, adding thermal insulation of a thickness of $200 \mathrm{~mm}$ from the inside

ures. Table 1 shows the surface temperature outputs for a perimeter wall based on $450 \mathrm{~mm}$ thick concrete.

As is clear from the previous results, when considering the additional thermal insulation of the floor in the basement with extruded polystyrene of a thickness of $100 \mathrm{~mm}$, the surface temperatures of the corner are higher when the external wall is additionally insulated from the inside. This is actually achieved by creating a thermal insulation screen over the entire inner surface, which ensures a higher temperature on the surface of the building envelope structures. However, this solution would not apply if it were not possible to insulate the ground floor in historic buildings (Figure 11). It can be seen in the given picture that the surface temperature without any floor insulation in the basement would certainly not satisfy the variant where we consider insulating the walls inside. It is interesting that the temperature is not linearly dependent when changing the thicknesses of the internal insulation (this issue will be the subject of further analysis). It should be mentioned when solving the issue by the 2D method that the critical surface temperatures would be suitable even when the external wall was additionally insulated from the outside. If only the $2 \mathrm{D}$ method were used in practice, there would be hygienic deficiencies that would be created in the corner analyzed. Therefore, in most cases, it is necessary to assess the critical details using the 3D method. Figure 12 shows the dependence of the surface temperatures on the thickness of the additional thermal insulation applied from the interior and exterior sides.

\subsection{The building's energy efficiency}

In addition to the analysis of the critical surface temperature of the detail selected, an analysis of the impact of the addition-

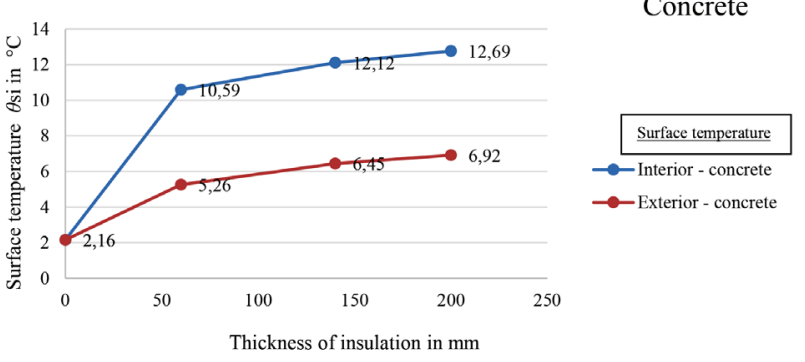

Fig. 12 Temperature profile for a variant with a concrete loadbearing structure

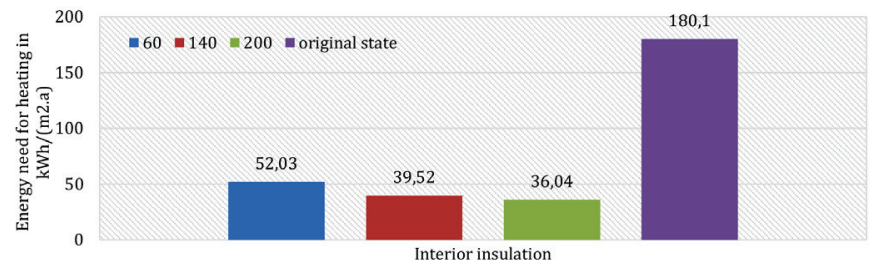

Fig. 13 Comparison of the heat demands for heating when adding thermal insulation from the interior

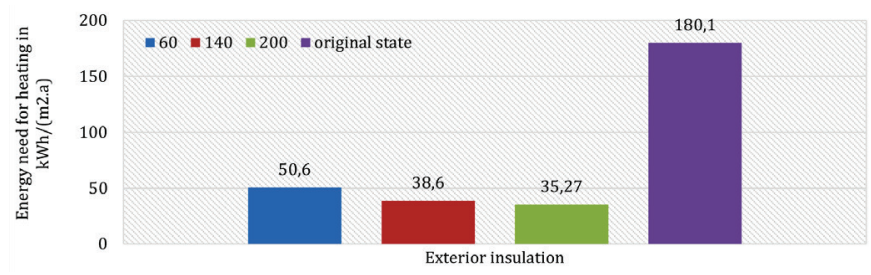

Fig. 14 Comparison of the heat demands for heating with external insulation

al interior or exterior thermal insulation on the building's energy efficiency was also performed. A method of calculating the heat demands for heating the entire building (basement and aboveground floors) on a monthly basis was considered. The resulting outputs are shown in the above graphs (Figures 13 and 14).

As can be seen from the previous results, the heat demands for heating calculated are more favorable when using thermal insulation from the outside (Figures 13 and 14). The results take into account the effect of thermal bridges and demonstrate the different values when considering additional thermal insulation on the inside of the basement wall and when applying it outside of the building envelope. When adding insulation to the internal walls, the main risk, in addition to the extent of the temperatures, is also the extent of the humidity. Only one detail was analyzed in this

Tab. 3 Surface temperatures of the reinforced concrete load-bearing wall

\begin{tabular}{|c|c|c|c|c|c|}
\hline Variant & $\begin{array}{l}\text { Insulation thickness } \\
\text { in } \mathrm{mm}\end{array}$ & Insulation position & $\begin{array}{l}\text { Surface temperature } \\
\theta_{\text {si }} \text { in }{ }^{\circ} \mathrm{C}\end{array}$ & $\begin{array}{l}\text { Required surface tem- } \\
\text { perature } \theta_{\text {si, }} \text { in }{ }^{\circ} \mathrm{C}\end{array}$ & $\begin{array}{l}\text { Assessment according to } \\
\text { STN } 730540-2: 2012+Z 1+Z 2\end{array}$ \\
\hline 0 & 0 & - & 2.16 & 13.1 & Does not meet the standard \\
\hline 1 & 60 & Interior & 10.59 & 13.1 & Does not meet the standard \\
\hline 2 & 140 & Interior & 12.12 & 13.1 & Does not meet the standard \\
\hline 3 & 200 & Interior & 12.69 & 13.1 & Does not meet the standard \\
\hline 4 & 60 & Exterior & 5.26 & 13.1 & Does not meet the standard \\
\hline 5 & 140 & Exterior & 6.45 & 13.1 & Does not meet the standard \\
\hline 6 & 200 & Exterior & 6.92 & 13,1 & Does not meet the standard \\
\hline
\end{tabular}


case study. However, we can state that many more critical details can arise when adding thermal insulation from the inside than when applying thermal insulation from the outside. Examples include the details of the window lining and back, details of the masonry with a wall beam in the attic, details of the awning (above the entrance to the building), etc., especially in reinforced concrete structures.

\section{DISCUSSION}

When considering concrete walls and brick walls, different surface temperatures are mainly affected by different coefficients of the thermal conductivity of the materials. As the coefficient of the thermal conductivity of the concrete is higher in comparison with the coefficient of the brick masonry construction of the above-ground floors, the details of the basement with reinforced walls were primarily examined.

From the results of examining the building's energy efficiency and from the energy criteria itself, we find that the building does not meet the requirements of standard STN $730540-2+Z 1+Z 2$ (2019) for the heat demands for heating, even after adding thermal insulation. The insufficient values are caused by large heat losses from the ventilation and infiltration of the original window and door structures. To achieve favourable results of the parameters evaluated, recuperation units would be an ideal solution. However, it is also not suitable for the intended function for reasons of the protection of the architectural work. This is one of the reasons why historical monuments have an exception in terms of meeting the requirements for energy efficiency.

\section{CONCLUSION}

The outputs themselves document the complexity of the preparatory phase in the process of the restoration of cultural monuments. Based on the available data, such as the research on the monument itself, the requirements of the Municipal Monument Preservation Institute in Nitra, geodetic surveys, architectural studies, etc., the possible modifications of the given building structure were defined. When planning the renovation of this building, it is necessary to keep the design and building processes in accordance with the requirements of the Municipal Monument Preservation Institute. On the other hand, it is necessary to consider the economic viability of the building construction.

In order to increase the real operation of monuments and the comfort of their indoor environments, it is necessary to determine the thermal properties and calculate the energy needs of such buildings. From assessing the details, values were obtained that indicate how the location of the thermal insulation would affect the values of the surface temperature, thermal resistance, and heat transfer coefficient. According to the standard STN 730540 $-2+\mathrm{Z} 1+\mathrm{Z} 2$ (2019), adding the thermal insulating material to the exterior as well as the interior of the basement walls, met the requirements only at the assessed thickness of $200 \mathrm{~mm}$. From the results of examining the energy efficiency of the building and energy criteria, we find that the building does not meet the requirements of standard STN 73 0540-2 + Z1 + Z2 (2019) for the heat demands for heating. The results of the analysis show that the most appropriate way to achieve the required determinants of energy intensity is adding thermal insulation from the outside.
Insufficient values were also caused by high heat losses due to ventilation and infiltration. The reduction of heat losses can be achieved by repairing the original wooden and metal window and door structures on the assessed building with its architectural and historical values.

\section{Acknowledgment}

This research was made within the scope of the KEGA 016STU-4/2017 national project. The project presented in this article is supported by the Ministry of Education, Science, Research and Sport of the Slovak Republic under VEGA No. 1/0042/21, VEGA No. 1/0680/20 and VEGA No. 01/0229/21. 


\section{REFERENCES}

Polomová, B. - Kvasnicová, M. - Urlandová, A. - Šperka, E. (2017) Pre-project preparatory verification studies as a suitable training model for built heritage restoration courses - example of modernisation of 20th century architecture (Overovacia štúdia $v$ predprojektovej príprave ako vhodný model výuky obnovy historickej architektúry - priklad modernizácie architektúry 20.storočia). In Architecture in Perspective 2017 : Sborník př́íspěvků z 9. mezinárodní konference. Architecture in Perspective, Architektura v perspektivě 2017. Ostrava, ČR, 2. - 3. 11. 2017, Architektúra v perspektivě 2017. Ostrava : Vysoká škola báňská - Technická univerzita Ostrava, 2017, pp. 218-225. ISBN 978-80-248 4058-1.

Kobetič, A. (2020) Bojovat' proti vírusom obnovou pamiatok? (Fight viruses by restoring monuments?) In: Eurostav Oct. 2020. ISSN 1335-1249

Energy efficiency: Energy Performance of Buildings. (2002) Directive 2002/91/EC.

Energy End-Use Efficiency and Energy Services and Repealing Council Directive 93/76/EEC. (2006). Directive 2006/32/EC.

Energy Performance of Buildings. (2010) Directive 2010/31/EC.

Tadeu, A. - Simões, I. - Simões, N. - Prata, J. (2011) Simulation of dynamic linear thermal bridges using a boundary element method model in the frequency domain. Energy Build. 43, pp. 3685-3695. https://doi.org/10.1016/j.enbuild.2011.10.001.

Act No. 300/2012. "Amending and supplementing Act No. $555 / 2005$ on the energy performance of buildings and on amendments to certain acts, as amended, and amending and supplementing Act No. 50/1976 on land-use planning and the building code (Building Act), as amended", Bratislava, Slovakia.

Ingeli, R. - Podhorec, J. - Čekon, M. (2016) Thermal Bridges Impact on Energy Need for Heating in Low Energy Wooden House, In: Applied Mechanics and Materials, 820, pp. 139-145. https://doi.org/10.4028/www.scientific.net/ AMM.820.139.

Theodosiou, T.G. - Papadopoulos, A.M. (2008) The impact of thermal bridges on the energy demand of buildings with double brick wall constructions, Energy and Buildings 40, pp. 2083-2089.
Buday, P. - Ingeli, R. - Čekon, M. (2014) Influence of Thermal Break Element Applied in Balcony Slab on Internal Surface Temperature. In: Advanced Materials Research, Vol. 1057, pp. 79-86.

Matiašovský, P. - Mihálka P. (2012) Catalog of construction solutions for application of capillary active thermal insulation system on historical objects. Bratislava: Institute of Construction and Architecture of SAV, ISBN 978-80-971077.

Meier, H.R. (2010) Geschichte und Theorie der Denkmalpflege: TU Dresden.

Zumoberhaus, M. (2009) Die Wärmedämmung von historischen Gebäuden aus bauphysikalischer Sicht, http://www.heimatschutz.ch/zeitschrift

Kastner, R. (2004) Altbauen Beurteilen, Bewerten. Stuttgart: Fraunhofer IRB Verlag.

Williams Portal, N.L. (2011) Evaluation of heat and moisture induced stress and strain of historic building materials and artefacts. Goteborg, Sweden, Master's Thesis.

STN 73 0540-2 (2012), Thermal protection of buildings. Thermal performance of buildings and components. Part 2: Functional requirements", Slovak Office of Standards, Metrology and Testing (SUTN), Bratislava, Slovak Republic.

Katunsky, D. - Katunska, J. - Labovska, V. Selected problems of thermal insulation of historical buildings. In: Journal of Civil Engineering Vol. 14, No. 1, 2019, pp. 67 - 74. (DOI: 10.1515/sspjce-2019-0007).

Psi-Therm 2D Enterprise 2017, PLUS Psi-Therm 3D 2017. (https://www.psitherm.uk/psi-features/psi-therm-3d-features).

STN EN ISO 13790 (2008) Energy performance of buildings. Calculation of energy use for space heating and cooling.

STN 73 0540-2+Z1+Z2 (2019), Thermal protection of buildings. Thermal performance of buildings and components. Part 2: Functional requirements. Slovak Office of Standards, Metrology and Testing (SUTN), Bratislava, Slovak Republic. 